\title{
Níveis de proteína digestível e energia digestível em dietas para tilápias-do- nilo formuladas com base no conceito de proteína ideal ${ }^{1}$
}

\author{
Giovani Sampaio Gonçalves², Luiz Edivaldo Pezzato ${ }^{3}$, Margarida Maria Barros ${ }^{3}$, Hamilton \\ Hisano $^{3}$, Maria Julia Santa Rosa ${ }^{4}$
}

\author{
1 Projeto de pesquisa financiado pela FAPESP \\ 2 Instituto de Pesca de São José do Rio Preto-SP. Rod. Washington Luiz, km 445. Caixa Postal 1052 - CEP: 15025-970. \\ ${ }^{3}$ Departamento de Melhoramento e Nutrição Animal, AquaNutri, FMVZ - Campus de Botucatu, SP. \\ ${ }^{4}$ Programa de Pós-Graduação do Centro de Aqüicultura da Unesp-Caunesp - Campus de Jaboticabal.
}

RESUMO - Este estudo foi realizado para determinar a melhor relação energia digestível/proteína digestível em rações formuladas com base em aminoácidos digestíveis e aplicando-se do conceito de proteína ideal para juvenis $(30,0 \pm 4,21 \mathrm{~g})$ de tilápia-do-nilo (Oreochromis niloticus). Foram formuladas 12 rações com 22,0;26,0;30,0 ou 34,0\% de proteína digestível e $3.000,3.300$ ou $3.600 \mathrm{kcal} / \mathrm{kg}$ de energia digestível, com relação proteína digestível/energia digestível variando entre 8,94 e $15,19 \mathrm{kcal} / \mathrm{g}$. Foram utilizadas 324 tilápias, distribuídas aleatoriamente em 36 aquários circulares com volume de 250 litros, em densidade de 9 peixes/aquário, perfazendo 12 tratamentos e 3 repetições. Ao final de 60 dias, não foi observada diferença no ganho de peso, no ganho de peso diário e na conversão alimentar entre as relações energia/proteína avaliadas. Entretanto, observou-se aumento linear do rendimento de filé com o aumento dos níveis de proteína digestível. O custo de ração por $\mathrm{kg}$ de ganho de peso foi menor nos peixes alimentados com a ração com $30,0 \% \mathrm{PD}$ e $3.000 \mathrm{kcal} / \mathrm{kg} \mathrm{ED}$, os quais apresentaram também melhor índice de eficiência econômica. A energia digestível não influenciou o desempenho produtivo, portanto, é possível a utilização de níveis inferiores a 34,0\% proteína digestível em rações com base no conceito de proteína ideal para juvenis de tilápia.

Palavras-chave: aminoácido, exigência proteica, nutrição, Oreochromis niloticus

\section{Level of digestible protein and digestible energy in diets for Nile tilapia formulated based on the concept of ideal protein}

\begin{abstract}
This study was carried out to determine the best digestible energy and digestible protein ratio in feeds for Nile tilapia (Oreochromis niloticus) juveniles $30.0 \pm 4.21 \mathrm{~g}$ ) based on digestible amino acids and the ideal protein concept). Twelve rations were formulated with protein levels $22.0 ; 26.0 ; 30.0$ and $34.0 \%$ of digestible protein and levels $3,000,3,300$ and $3,600 \mathrm{kcal} / \mathrm{kg}$ digestible energy. The digestible energy/digestible protein ratio was between 8.94 and $15.19 \mathrm{kcal} / \mathrm{g}$. Three hundred and twenty four tilapias were randomly distributed in thirty six $250 \mathrm{~L}$ circular tanks at a density of $9 \mathrm{fish} / \mathrm{tank}$, a total of 12 treatments with three replications. After 60 days, there was no significant difference in weight gain, daily weight gain and feed conversion ratio among the studied treatments. A linear increase was observed in fillet yield with increasing digestible protein. With respect to feed cost $/ \mathrm{kg}$ weight gain, the treatment with $30.0 \% \mathrm{DP}$ and $3,000 \mathrm{kcal} / \mathrm{kg} \mathrm{DE}$ presented low cost and better cost effectiveness index. Therefore, it was concluded that digestible energy did not influence the productive performance parameters and that effective feeds can be formulated with DP levels lower than $34 \%$ when feeding juvenile tilapias. The ration should be formulated based on the concept of ideal protein.
\end{abstract}

Key Words: amino acids, nutrition, Oreochromis niloticus, protein requirement

\section{Introdução}

Os peixes obtêm a energia do alimento ou, quando em jejum, das reservas corporais e apresentam baixa exigência em energia em comparação aos animais homeotérmicos, por isso, são considerados mais eficientes que os mamíferos e pássaros (NRC, 1993).
O alto nível de proteína utilizado em dietas para peixes decorre do hábito alimentar da espécie, bem como à característica de utilizarem, produtos do catabolismo de proteína em vez de carboidratos e lipídios como principal fonte de energia (Tacon \& Cowey, 1985), suprindo suas exigências de forma alternativa e pouco econômica. Assim, o uso de fontes alternativas de energia, como lipídios e 
carboidratos, e o correto balanceamento desses nutrientes para atender à exigência da espécie permite melhor utilização dos aminoácidos para crescimento das fibras musculares e manutenção metabólica.

Muitos estudos realizados para determinar a exigência em proteína para as espécies utilizadas na aquicultura podem apresentar valores superestimados, uma vez que parte dos aminoácidos da dieta pode ser catabolizada na forma de esqueleto carbônico-carboidrato e gorduras e utilizada como fonte de energia pelos peixes, aumentando o custo da alimentação (Wilson, 1989; Lovell, 1989) e a excreção de amônia para o meio, além dos efluentes com maior potencial poluente (Kaushik \& Oliva-Teles, 1986).

Entre os principais fatores que influenciam a exigência proteica na alimentação dos peixes estão a qualidade da proteína, o teor de energia dietética não-proteica (carboidratos e lipídios) e a relação energia proteína (Brandt, 1991). A concentração ótima de proteína em rações para peixes é obtida pelo balanço entre energia digestível (ED) e proteína bruta (PB) (Cho, 1992). Um excesso de energia não-proteica, como resultado da formulação com alta relação ED/PB, pode inibir a ingestão voluntária (Page \& Andrews, 1973) antes do consumo suficiente da dieta e dos aminoácidos, o que prejudica a utilização de outros nutrientes, uma vez que o consumo tem sido determinado fundamentalmente pelo conteúdo de energia disponível na dieta (Colin et al., 1993). Por outro lado, ração deficiente em energia em relação à proteína diminui a taxa de crescimento (NRC, 1993).
Este estudo foi realizado com o objetivo de avaliar o desempenho de juvenis de tilápia-do-nilo (Oreochromis niloticus) alimentados com rações com diferentes níveis de proteína digestível e energia digestível, formuladas com base no conceito de proteína ideal.

\section{Material e Métodos}

O experimento foi realizado na Unesp - Universidade Estadual Paulista, Faculdade de Medicina Veterinária e Zootecnia, Departamento de Melhoramento e Nutrição, Laboratório de Nutrição de Organismos Aquáticos Aquanutri, unidade integrada ao Centro de Aquicultura da UNESP.

Utilizaram-se 12 rações com $3.000,3.300$ ou $3.600 \mathrm{kcal} / \mathrm{kg}$ de energia digestível e 22,$0 ; 26,0,30,0$ ou $34,0 \%$ de proteína digestível (Tabela 1), formuladas com base no conceito de proteína ideal utilizando-se como referência o perfil de aminoácidos no filé de juvenis de tilápia (Tabela 2). As rações foram formuladas para apresentar diferentes relações energia digestível:proteína digestível, variando de 8,94 a 16,19 kcal energia digestível por grama de proteína digestível, isofosfóricas e isocalcíticas (Tabela 3). Os alimentos utilizados nas rações experimentais foram moídos em moinho de facas para obtenção de partículas entre 0,6 e $0,8 \mathrm{~mm}$. As rações foram homogeneizadas mecanicamente e posteriormente umedecidas $(20,0 \%$ água) e extrusadas em extrusora comercial de forma a se

Tabela 1 - Composição das rações experimentais (\% matéria natural)

\begin{tabular}{|c|c|c|c|c|c|c|c|c|c|c|c|c|}
\hline \multirow[t]{2}{*}{ Ingrediente } & \multicolumn{12}{|c|}{ Proteína digestível (\%):energia digestível (kcal/kg) } \\
\hline & $22 / 3.000$ & $22 / 3.300$ & $22 / 3.600$ & $26 / 3.000$ & $26 / 3.300$ & $26 / 3.600$ & $30 / 3.000$ & $30 / 3.300$ & $30 / 3.600$ & $34 / 3.000$ & $34 / 3.300$ & $34 / 3.600$ \\
\hline Farelo de soja & 33,10 & 33,90 & 39,55 & 42,40 & 43,20 & 49,60 & 52,00 & 52,90 & 60,10 & 49,20 & 51,00 & 59,39 \\
\hline Levedura de cana & 2,00 & 2,00 & 2,00 & 2,00 & 2,00 & 2,00 & 2,00 & 2,00 & 2,00 & 2,00 & 2,00 & 2,00 \\
\hline Farelo de algodão & 7,53 & 7,53 & 0,00 & 8,91 & 8,91 & 0,00 & 10,27 & 10,28 & 0,00 & 11,65 & 11,65 & 0,00 \\
\hline Protenose & 0,00 & 0,00 & 0,00 & 0,00 & 0,00 & 0,00 & 0,00 & 0,00 & 0,00 & 9,75 & 8,00 & 8,00 \\
\hline Milho & 19,35 & 30,67 & 36,00 & 7,53 & 25,10 & 28,60 & 0,00 & 14,86 & 18,64 & 0,00 & 6,82 & 11,00 \\
\hline Farelo de trigo & 5,00 & 5,00 & 5,00 & 5,00 & 5,00 & 5,00 & 5,00 & 5,00 & 5,00 & 5,00 & 5,00 & 5,00 \\
\hline Arroz quirera & 23,62 & 8,00 & 0,00 & 25,81 & 5,00 & 0,00 & 22,82 & 3,97 & 0,00 & 7,80 & 4,00 & 0,00 \\
\hline Amido & 0,00 & 0,00 & 0,00 & 0,00 & 0,00 & 0,00 & 0,00 & 0,00 & 0,00 & 6,33 & 0,00 & 0,00 \\
\hline Celulose & 1,35 & 1,20 & 2,10 & 0,30 & 0,00 & 0,40 & 0,00 & 0,00 & 0,00 & 0,00 & 0,00 & 0,00 \\
\hline L-lisina & 0,60 & 0,60 & 0,55 & 0,65 & 0,66 & 0,55 & 0,70 & 0,70 & 0,56 & 1,15 & 1,10 & 0,93 \\
\hline DL-metionina & 0,40 & 0,40 & 0,40 & 0,50 & 0,48 & 0,47 & 0,55 & 0,55 & 0,55 & 0,57 & 0,58 & 0,57 \\
\hline Treonina & 0,35 & 0,40 & 0,40 & 0,40 & 0,39 & 0,38 & 0,45 & 0,45 & 0,45 & 0,55 & 0,55 & 0,51 \\
\hline Óleo de soja & 0,00 & 3,60 & 7,30 & 0,00 & 2,70 & 6,40 & 0,00 & 3,00 & 6,20 & 0,00 & 3,20 & 6,30 \\
\hline Fosfato bicálcico & 5,70 & 5,80 & 6,00 & 5,50 & 5,76 & 5,90 & 5,50 & 5,60 & 5,8 & 5,30 & 5,40 & 5,60 \\
\hline Calcário & 0,30 & 0,20 & 0,00 & 0,30 & 0,10 & 0,00 & 0,00 & 0,00 & 0,00 & 0,00 & 0,00 & 0,00 \\
\hline Vitamina $C^{1}$ & 0,08 & 0,08 & 0,08 & 0,08 & 0,08 & 0,08 & 0,08 & 0,08 & 0,08 & 0,08 & 0,08 & 0,08 \\
\hline Sal & 0,10 & 0,10 & 0,10 & 0,10 & 0,10 & 0,10 & 0,10 & 0,10 & 0,10 & 0,10 & 0,10 & 0,10 \\
\hline $\begin{array}{l}\text { Suplemento vitamínico } \\
\text { e } \text { mineral }^{2}\end{array}$ & 0,50 & 0,50 & 0,50 & 0,50 & 0,50 & 0,50 & 0,50 & 0,50 & 0,50 & 0,50 & 0,50 & 0,50 \\
\hline Butil-hidroxi-tolueno $^{3}$ & 0,02 & 0,02 & 0,02 & 0,02 & 0,02 & 0,02 & 0,02 & 0,02 & 0,02 & 0,02 & 0,02 & 0,02 \\
\hline
\end{tabular}


obterem grânulos de 1,7 a 4,0 mm, utilizados conforme o tamanho dos peixes durante o período experimental. Depois de extrusadas, as rações foram secas em estufa de ventilação forçada durante 12 horas a $55,0{ }^{\circ} \mathrm{C}$.

Utilizaram-se 324 juvenis de tilápia-do-nilo (Oreochromis niloticus) provenientes da Piscicultura Aquabel, linhagem tailandesa, revertidos sexualmente e com peso inicial de 30,0 $\pm 4,21 \mathrm{~g}$, distribuídos aleatoriamente em 36 aquários circulares com volume de 250 L. Os

Tabela 2 - Relação entre os aminoácidos do filé da tilápias-donilo considerando a lisina com aminoácido-referência $(100,00 \%)$

\begin{tabular}{lcc}
\hline Aminoácido $^{1}$ & Filé $(\%)$ & Relação $^{2}$ \\
\hline Lisina & 8,31 & 100,00 \\
Alanina & 5,79 & 69,75 \\
Arginina & 5,36 & 64,57 \\
Ácido aspártico & 10,19 & 122,73 \\
Glicina & 5,27 & 63,39 \\
Isoleucina & 4,45 & 53,58 \\
Leucina & 7,38 & 88,87 \\
Ácido glutâmico & 15,15 & 182,37 \\
Cistina & 0,51 & 6,17 \\
Metionina & 2,45 & 29,50 \\
Fenilalanina & 3,83 & 46,06 \\
Tirosina & 2,48 & 29,88 \\
Treonina & 4,30 & 51,81 \\
Triptofano & 1,05 & 12,59 \\
Prolina & 3,19 & 38,44 \\
Valina & 4,83 & 58,21 \\
Histidina & 2,20 & 26,43 \\
Serina & 3,52 & 42,34 \\
\hline
\end{tabular}

${ }^{1}$ Valor expresso na matéria seca.

2 Valor percentual em relação ao aminoácido lisina. aquários faziam parte de um sistema fechado de recirculação de água, com aeração, aquecimento controlado por meio de aquecedores elétricos ligados a termostato $\left(27,0 \pm 1,0^{\circ} \mathrm{C}\right)$ e filtragem física e biológica da água por meio de biofiltro. Os peixes foram distribuídos em delineamento experimental inteiramente casualisado com 12 tratamentos em esquema fatorial $3 \times 4$, composto de três níveis de energia digestível e quatro níveis de proteína digestível, com três repetições por tratamento e nove peixes por unidade experimental.

A alimentação foi realizada à vontade, seis vezes ao dia (das 8 às $18 \mathrm{~h}$ ) durante todo o período experimental (60 dias). Semanalmente, foi monitorada a qualidade da água ( $\mathrm{pH}$, oxigênio dissolvido, amônia e nitrito) e, quinzenalmente, foi realizada a limpeza do fundo dos aquários, por meio de sifonagem e reabastecimento de $30,0 \%$ do volume total de água.

Foram avaliados os seguintes índices de desempenho produtivo ao final do período experimental: consumo alimentar, ganho em peso, ganho em peso diário, conversão alimentar aparente, consumo alimentar diário, consumo diário de proteína digestível, taxa de eficiência protéica, sobrevivência, rendimento de filé, índice hepatossomático, índice víscerossomático, eficiência de retenção de proteína, extrato etéreo no fígado e gordura visceral.

Todos os peixes foram pesados no início e ao final dos 60 dias de experimento. Para isso, foram anestesiados (benzocaína $1 \mathrm{~g} / 20 \mathrm{~m}$ álcool/15 L água) e pesados individualmente em balança semianalítica. No final do

Tabela 3 - Composição e relação entre nutrientes e energia das rações experimentais (\% matéria natural)

\begin{tabular}{|c|c|c|c|c|c|c|c|c|c|c|c|c|}
\hline \multirow[t]{2}{*}{ Ingrediente } & \multirow[b]{2}{*}{$22 / 3.000$} & \multirow[b]{2}{*}{$22 / 3.300$} & \multicolumn{10}{|c|}{ Proteína digestível (\%):energia digestível $(\mathrm{kcal} / \mathrm{kg})$} \\
\hline & & & $22 / 3.600$ & $26 / 3.000$ & $26 / 3.300$ & $26 / 3.600$ & $30 / 3.000$ & $30 / 3.300$ & $30 / 3.600$ & $34 / 3.000$ & $34 / 3.300$ & $34 / 3.600$ \\
\hline Matéria seca (\%) & 95,10 & 94,37 & 94,51 & 94,99 & 93,45 & 95,40 & 94,18 & 94,72 & 95,45 & 94,70 & 95,44 & 95,48 \\
\hline Proteína bruta (\%) & 25,38 & 25,23 & 24,92 & 30,06 & 29,89 & 29,57 & 34,74 & 34,60 & 34,28 & 39,34 & 39,17 & 38,96 \\
\hline Proteína digestível ${ }^{2}(\%)$ & 22,15 & 22,09 & 22,07 & 26,13 & 26,04 & 25,99 & 30,10 & 30,04 & 30,02 & 34,03 & 33,94 & 34,01 \\
\hline $\begin{array}{l}\text { Relação energia digestível: } \\
\text { proteína digestível }\end{array}$ & 135,53 & 148,94 & 161,94 & 115,04 & 126,42 & 138,05 & 100,50 & 109,82 & 119,49 & 89,45 & 97,02 & 105,65 \\
\hline Fibra bruta $(\%)$ & 5,00 & 4,98 & 4,92 & 4,95 & 4,84 & 4,25 & 5,49 & 5,60 & 4,57 & 5,53 & 5,68 & 4,52 \\
\hline Extrato etéreo (\%) & 1,88 & 5,44 & 8,96 & 1,87 & 4,58 & 8,08 & 1,87 & 4,85 & 7,85 & 2,15 & 5,31 & 8,19 \\
\hline Cálcio (\%) & 1,99 & 1,99 & 2,01 & 2,02 & 2,03 & 2,08 & 1,99 & 2,04 & 2,15 & 1,99 & 2,03 & 2,15 \\
\hline Fósforo disponível ${ }^{3}(\%)$ & 0,75 & 0,74 & 0,75 & 0,75 & 0,76 & 0,75 & 0,76 & 0,75 & 0,76 & 0,75 & 0,75 & 0,75 \\
\hline Lisina digestível $^{3}(\%)$ & 1,76 & 1,75 & 1,79 & 2,08 & 2,08 & 2,09 & 2,40 & 2,40 & 2,40 & 2,73 & 2,73 & 2,72 \\
\hline
\end{tabular}

${ }^{1}$ Valores determinados no Laboratório de Bromatologia da Universidade Estadual Paulista - Unesp-Botucatu.

${ }^{2}$ Valores determinados em bomba calorimétrica Parr ${ }^{\circledR}$; Valor analisados no LabTec (Mogiana Alimentos). 
experimento, quatro peixes de cada repetição (12 peixes/ tratamento) foram sacrificados por secção da medula espinhal para avaliação do rendimento de filé, da composição do filé, dos índices hepatossomático e viscerossomático e da gordura visceral. As vísceras e o fígado foram congelados separadamente por meio de imersão em nitrogênio líquido para posteriormente serem quantificadas as porcentagens de gordura.

Foram retirados do lote inicial 20 peixes para análise da composição físico-química da carcaça e, ao final do período experimental, quatro peixes de cada repetição (12 peixes por tratamento) foram anestesiados (benzocaína $1 \mathrm{~g} / 20 \mathrm{~m}$ álcool/ 15 L água) e sacrificados por meio da secção da medula espinhal para posteriormente serem avaliados quanto à composição físico-química do filé (umidade, matéria seca proteína bruta, matéria mineral e extrato etéreo) e análise macroscópica das vísceras. As pesagens foram realizadas em balança analítica após 12 horas de jejum.

As composições físico-químicas dos filés e das rações foram determinadas de acordo com procedimentos da AOAC (1984) e AOAC (2000) e realizadas no Laboratório de Bromatologia do Departamento de Melhoramento e Nutrição da FMVZ, Unesp-Botucatu.

Os mesmos peixes utilizados na determinação da composição do filé foram utilizados nas análises hematológicas e de glicogênio hepático e muscular.

A contagem de eritrócitos foi realizada pelo método do hemocitômetro em câmara de Neubauer, utilizando-se azul de toluidina a $0,01 \%$ diluído em solução fisiológica 0,9\% em pipeta de Thoma, na proporção 1:200. A taxa de hemoglobina foi determinada pelo método da ciano-metahemoglobina, utilizando-se um kit hemoglobina de determinação colorimétrica. O hematócrito foi obtido pelo método do microhematócrito. A proteína plasmática total foi determinada por refratômetro manual de Goldenberg. Foram também calculados o volume corpuscular médio e a concentração de hemoglobina corpuscular média.

Para as análises de glicogênio (Bidinotto et al., 1997), amostras de fígado e músculo branco foram transferidas para tubo de ensaio (100 mg de tecido/mL de KOH 6,0N) e incubados por 3 minutos a $100^{\circ} \mathrm{C}$ em banho-maria. Após a dissolução alcalina dos tecidos, $250 \mu \mathrm{L}$ desses extratos eram transferidos para tubos de ensaio e adicionados de $3 \mathrm{~mL}$ de etanol e $100 \mu \mathrm{L}$ de $\mathrm{K}_{2} \mathrm{SO}_{4} 10 \%$ e submetidos à agitação. As amostras eram centrifugadas a $2.000 \mathrm{x} g$ por 1 minuto. O sobrenadante de cada tubo de reação foi descartado por inversão e o precipitado ressuspendido em 2,5 $\mathrm{mL}$ de água destilada. Um volume adequado dessa diluição foi analisado quanto ao teor de açúcares totais pelo método hidrolítico ácido de Dubois et al. (1956) e o conteúdo de glicogênio, expresso em $\mu$ moles de glicosil-glicose/g de tecido. As análises hematológicas foram realizadas no Laboratório de Nutrição de Organismos Aquáticos do Departamento de Melhoramento e Nutrição da FMVZUnesp-Botucatu e as análises de glicogênio, no Laboratório de Fisiologia da Universidade Federal de São Carlos.

Seis peixes de cada relação proteína:energia digestível foram utilizados para avaliação morfológica das estruturas histológicas do fígado. Foram anestesiados em benzocaína ( $1 \mathrm{~g} / 15 \mathrm{~L}$ de água) e sacrificados por secção da medula espinhal e o fígado foi reitrado, lavado em solução fisiológica $(0,9 \%)$ e fixado em solução formalina tamponada por 24 horas. Posteriormente, o material foi lavado em álcool $70,0 \%$ para retirada do fixador e, em seguida, incluído em historesina para realização dos cortes de $5 \mu \mathrm{m}$ do tecido hepático em micrótomo. Os cortes foram submetidos à coloração hematoxilina e eosina, segundo técnica descrita por Bancroft \& Stevens (1996). As análises foram realizadas no Laboratório de Morfologia e Histologia da Universidade Estadual Paulista - UNESP/ Botucatu.

No momento da formulação e do processamento das dietas experimentais, foram avaliados os custos por $\mathrm{kg}$ de ração e, ao final do experimento, foi realizada a análise da viabilidade econômica (custos de ração por kg de peso dos peixes), de acordo com a fórmula proposta por Bellaver et al. (1985). Após a obtenção dos valores de viabilidade econômica, realizou-se o índice de eficiência econômica, de acordo com Barbosa et al. (1992).

As análises de variância foram realizadas de acordo com o seguinte modelo:

$Y i j k=\mu+E D i+E D \times P D i j+\varepsilon i j k$, em que:

Yijk = produção observada na unidade experimental $\mathrm{k}$ do nível de proteína digestível i, no nível de energia digestível i; $\mu=$ média geral; $E D=$ efeito do nível de energia digestível; EDxPDi = efeito do nível de proteína digestível, dentro do nível de energia digestível; $\varepsilon i j k=$ erro aleatório associado a cada observação.

Nas análises estatísticas dos parâmetros avaliados, utilizou-se o programa Statistical Analysis System (SAS, 1995). Os resultados foram submetidos à análise de variância e, quando significativos $(\mathrm{P}<0,05)$, avaliados pela análise de contrastes ortogonais e pelo teste Tukey. A estimativa das exigências de proteína digestível estabelecida foi realizada por meio dos modelos de regressão linear e quadrático considerando na escolha do modelo a interpretação biológica dos resultados. 


\section{Resultados e Discussão}

A relação lisina digestível:proteína digestível foi de aproximadamente $8,0 \%$ para todas as rações, e os demais aminoácidos essenciais foram calculados para atender o conceito de proteína ideal (Tabela 3 ).

Não foi constatada mortalidade durante o período experimental. Não houve interação $(\mathrm{P}>0,05)$ entre os efeitos de energia digestível e proteína digestível para nenhum dos parâmetros de desempenho avaliados (Tabela 4). Os resultados obtidos para ganho de peso e ganho de peso diário, quando submetidos à análise de variância, não diferiram $(\mathrm{P}>0,05)$ entre os níveis de proteína digestível e energia digestível. O nível de energia não alterou o desempenho dos peixes, contudo, observou-se redução no consumo de alimento e na taxa de eficiência proteica, além de aumento no consumo de proteína, à medida que os níveis de proteína digestível aumentaram (Tabela 4).

Ainda que a energia possa ser utilizada como fator economizador de proteína para a tilápia-do-nilo (De-Silva et al., 1991), não foi observado efeito significativo nos parâmetros de desempenho produtivo, contrariando os resultados obtidos por Dupree et al. (1979) para o bagre-docanal (Ictalurus punctatus); Winfree \& Stickney (1981) para tilápia (S. aureus); De Silva et al. (1991) para tilápia híbrida vermelha; Sampaio (1999) para o tucunaré; e Portz (1999) para "black bass" (Micropterus salmoides).

Jantrarotai et al. (1998) estudaram o efeito economizador de proteína por meio de diferentes relações energia digestível: proteína bruta para alevinos de bagre (Clarias macrocephalus $\times$ Clarias gariepinus) e observaram maior influência da proteína em comparação aos níveis de energia (dextrina). Os melhores resultados foram obtidos com o mínimo de $2.750 \mathrm{kcal} \mathrm{ED} / \mathrm{kg}$ e o máximo de $40,0 \% \mathrm{~PB}$.

O nível proteico e energético para diferentes espécies de peixe tem sido avaliado em muitos estudos, entretanto, mesmo em condições ideais de experimentação e manejo, diferenças quanto à fase de crescimento e à dieta utilizada podem ocasionar variações nos valores de exigência. Nesse sentido, Hafedh (1999), em estudo com tilápias-do-nilo (Oreochromis niloticus), avaliou diferentes fases de criação e rações contendo níveis crescentes de proteína bruta e

Tabela 4 - Desempenho de juvenis de tilápia-do-nilo alimentados com rações contendo diversas relações energia digestível:proteína digestível, com base no conceito de proteína ideal

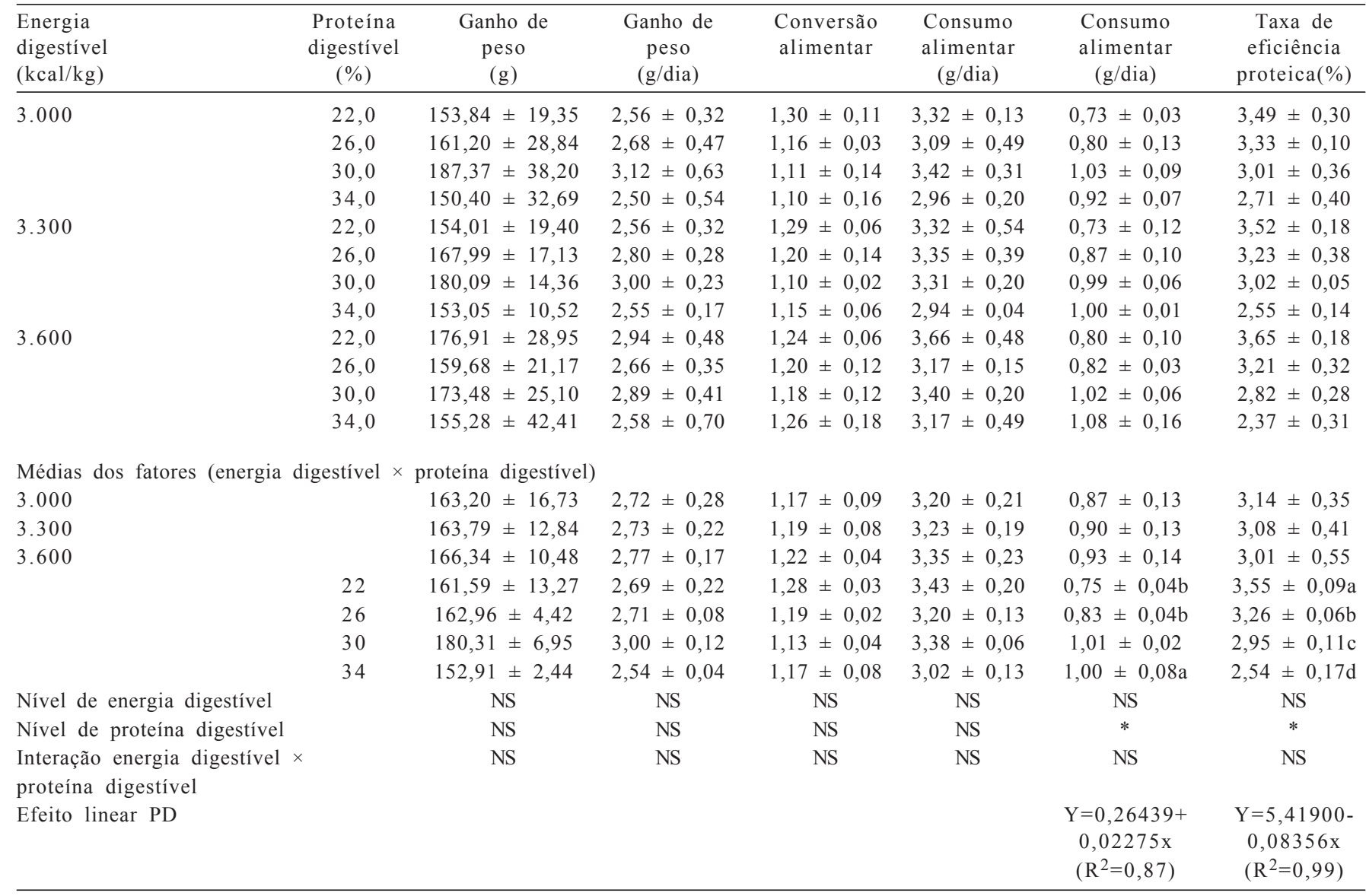

$\mathrm{NS}=(\mathrm{P}>0,05) ; *$ Efeito linear $(\mathrm{P}<0,05)$. 
observou melhor ganho de peso nos peixes com peso médio de 96,0 e 264,0 g alimentados com rações contendo entre 30,0 e $45,0 \%$ PB.

Nesse estudo, nenhuma diferença foi observada no ganho de peso, no ganho de peso diário e no consumo aparente entre os níveis de proteína digestível, energia digestível e suas interações. Estes resultados comprovam a possibilidade de redução nos níveis proteicos e energéticos das rações utilizadas para tilápias-do-nilo, desde que os demais nutrientes, incluindo os aminoácidos, estejam dentro da faixa de exigência para ótimo crescimento da espécie. Formulações para atender às exigências em proteína e aminoácidos podem ser elaboradas pelo conceito de proteína ideal, que permite correto balanceamento utilizando como referência o perfil de aminoácidos da carcaça ou do filé do peixe. Desta forma, a proporcionalidade entre aminoácidos direciona para a correta formulação, uma vez que as quantidades são definidas de acordo com a exigência de proteína e lisina de cada espécie, já que os peixes não possuem exigência verdadeira de proteína, mas sim de adequado balanceamento entre os aminoácidos essenciais (Wilson \& Poe, 1985; Wilson, 1989).

Uma vez utilizado o conceito de proteína ideal, a proteína da dieta passa a ser uma fonte de aminoácidos que atende às exigências dos dez aminoácidos essenciais, tendo como referência o nível ótimo de lisina. Dessa forma, o fornecimento adequado de lisina na dieta permite o correto balanceamento dos demais aminoácidos essenciais, em decorrência de sua alta correlação entre o perfil de aminoácidos da carcaça e o exigido pelo peixe (Akiyama et al., 1997), e possibilita a redução do nível proteico a partir da utilização de alimentos cujos aminoácidos sejam de alto valor biológico.

A utilização de aminoácidos sintéticos (lisina, metionina, treonina e triptofano) permite a formulação de rações com elevados níveis desses aminoácidos, considerados mais limitantes para as rações. Por outro lado, Yamada et al. (1981) relataram menor desempenho de truta arco-íris alimentadas com rações contendo aminoácidos sintéticos, devido à rápida absorção. Ressalta-se que o fornecimento de aminoácidos cristalinos e de níveis ideais dos demais aminoácidos essenciais contidos nos alimentos permite o balanceamento ideal do nível de proteína, fato que explica a melhor utilização da fração proteica pelo conceito de proteína ideal, o que contraria as afirmações de Yamada et al. (1981).

Os resultados obtidos neste estudo confirmam a possibilidade de redução do nível de proteína sugerido por Furuya et al. (2005) para a espécie, de $27,5 \%$ de proteína digestível e relação energia digestível:proteína digestível de $11,27 \mathrm{kcal} / \mathrm{g}$ com peso médio de até $120,0 \mathrm{~g}$, utilizando o conceito de proteína ideal para o correto balanceamento de aminoácidos.

Não foi observado efeito significativo dos níveis de energia e proteína digestíveis nem de suas interações para a conversão alimentar. Colin et al. (1993) destacaram que os níveis de ingestão são controlados pelo nível de energia disponível na ração. Neste estudo, a energia digestível não influenciou a quantidade de ração ingerida, fato observado somente quando houve aumento $(\mathrm{P}<0,05)$ no consumo de proteína na ração. Esse fato pode ser explicado pelo sinergismo entre proteína e energia, uma vez que a proteína pode ser utilizada como fonte de energia para o peixe, e pela regulação da exigência em aminoácidos, em virtude do aumento $(\mathrm{P}<0,05)$ no consumo diário de proteína.

$\mathrm{O}$ aumento nos níveis de proteína e energia digestível na ração não teve efeito $(\mathrm{P}>0,05)$ no consumo alimentar diário, o que contraria os resultados de Page \& Andrews (1973), que apresentam a possibilidade de inibição da ingestão voluntária antes que haja o consumo de quantidade suficiente de aminoácidos, prejudicando a utilização de outros nutrientes, devido ao excesso de energia nãoproteica, como resultado da formulação de rações com alta relação energia digestível:proteína bruta.

Neste estudo, os melhores valores obtidos com o uso de baixos níveis proteicos e rações formuladas com base no conceito de proteína ideal podem ser identificados por meio da taxa de eficiência proteica, que foi afetada de forma linear decrescente $(\mathrm{P}<0,05)$ pelo nível de proteína digestível nas rações, independentemente do nível de energia digestível. Respostas similares foram observadas por Rodehutscord et al. (2000) com truta arco-íris e Furuya et al. (2004a) e Furuya et al. (2005) com juvenis de tilápia-do-nilo.

Não houve efeito das relações energia digestível:proteína digestível sobre a gordura visceral, o extrato etéreo do fígado e os índices hepatossomático e viscerossomático (Tabela 5). Entretanto, a eficiência de retenção de proteína e o rendimento de filé diferiram significativamente $(\mathrm{P}<0,05)$ somente quando analisados os níveis de proteína digestível, independentemente do nível de energia digestível da ração, e não foi constatada interação entre os dois fatores.

O rendimento de filé aumentou de forma linear de acordo com os níveis de proteína digestível da ração (Figura 1). Furuya et al. (2004a) não observaram aumento significativo no rendimento de carcaça ao avaliarem a utilização de níveis crescentes de lisina $(1,13 ; 1,27 ; 1,42$ e 1,57\%) em rações com baixo nível proteico $(25,0 \% \mathrm{~PB})$ em tilápias-do-nilo $(117,0 \mathrm{~g})$. Entretanto, Furuya et al. (2005), com o objetivo de avaliar a aplicação do conceito de proteína ideal para a redução dos níveis de proteína para tilápias-do-nilo, constataram que 
Tabela 5 - Desempenho produtivo de juvenis de tilápia-do-nilo alimentadas com diferentes relações energia digestível:proteína digestível formuladas com base no conceito de proteína ideal

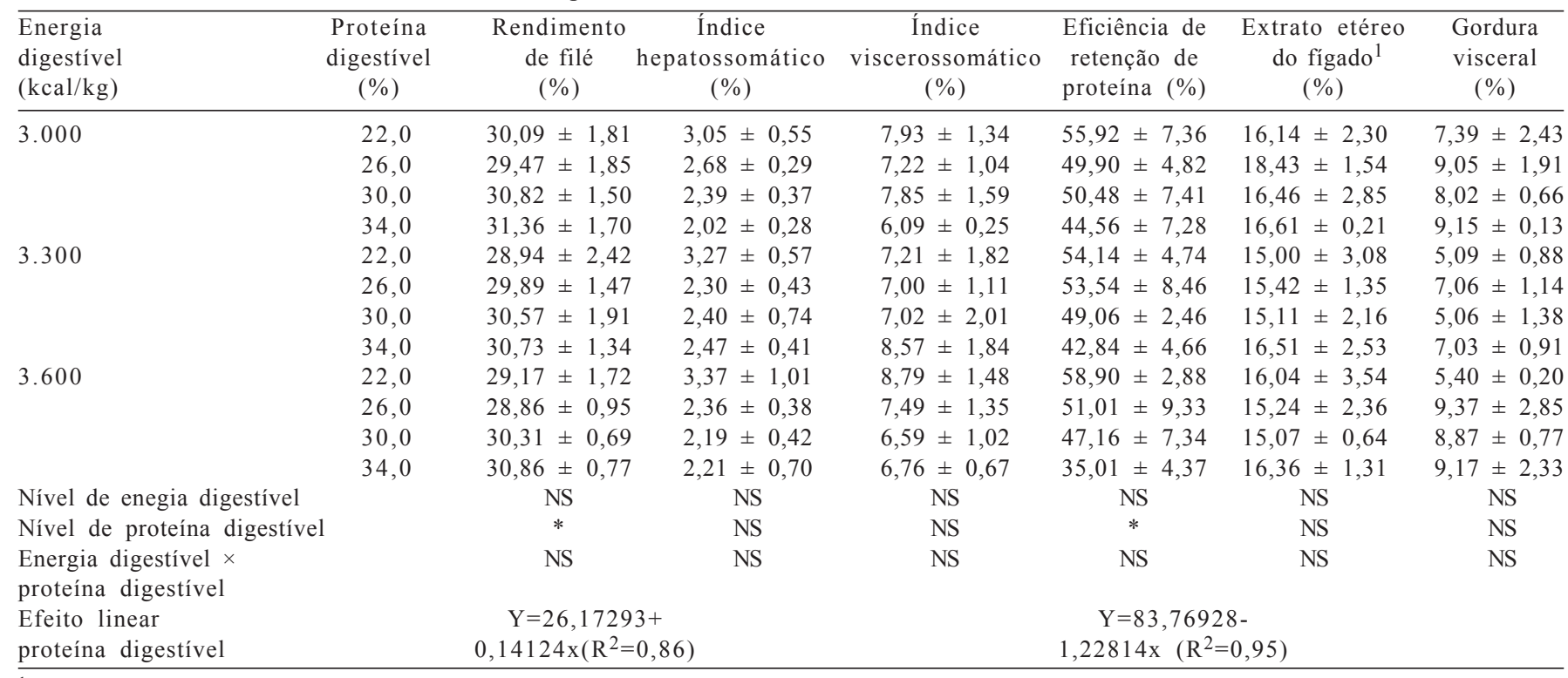

${ }^{1}$ Valor expresso com base na matéria seca; $*=\mathrm{P}<0,05 ; \mathrm{NS}=\mathrm{P}>0,05$ pelo teste de $\mathrm{F}$.

níveis de até $27,7 \%$ de proteína digestível e 1,7\% de lisina foram os que promoveram melhores respostas para o máximo rendimento de carcaça. Os valores encontrados neste estudo e os resultados de pesquisas apresentados permitem ressaltar a eficiência de utilização dos aminoácidos quando fornecidos em proporções adequadas, o que torna possível a obtenção de melhores respostas quanto ao rendimento de filé, mesmo utilizando rações com baixos níveis proteicos, porém formuladas de modo a atender a exigência em todos os aminoácidos essenciais.

Uma vez que a tilápia pode utilizar eficientemente os aminoácidos presentes nas rações, sejam eles na forma

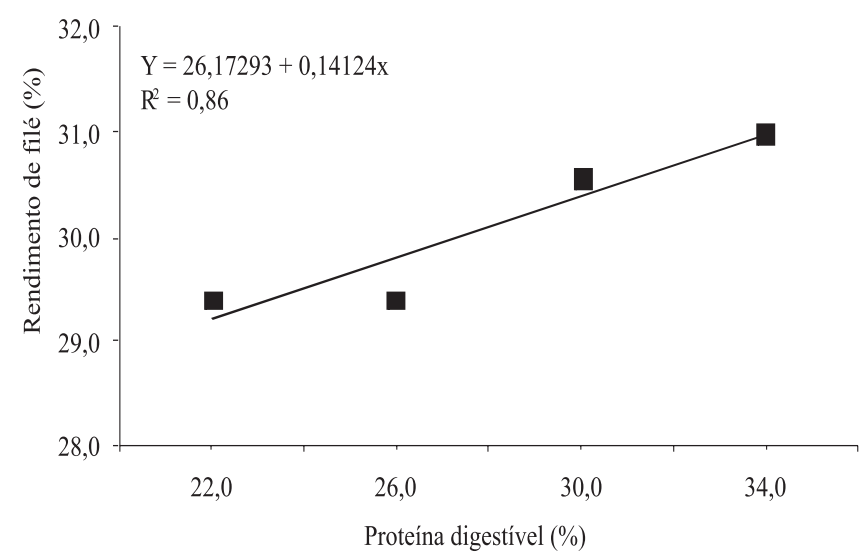

Figura 1 - Rendimento de filé de tilápia-do-nilo alimentadas com rações contendo níveis crescentes de proteína digestível. cristalina ou ligada à proteína, a aplicação do conceito de proteína ideal na formulação das rações permite a obtenção de melhores resultados com níveis mais baixos de proteína digestível. O maior aproveitamento de níveis inferiores de proteína, sem prejudicar as demais variáveis analisadas, pode ser constatado pela eficiência de retenção proteica, a qual apresentou diferença significativa $(\mathrm{P}<0,05)$ apenas os níveis de proteína digestível e reduziu linearmente com o aumento desse nutriente nas rações.

Nas análises da composição química do filé (Tabela 6), incluindo os teores de umidade, proteína bruta e matéria mineral, não houve diferenças entre as relações energia digestível:proteína digestível. Entretanto, verificou-se efeito significativo dos níveis de energia digestível, proteína digestível e suas interações sobre o teor de gordura. Nos níveis de 3.000 e $3.300 \mathrm{kcal} / \mathrm{kg}$ de energia digestível, a variação dos resultados entre os níveis de proteína digestível foi quadrática (Tabela 6), com o ponto de máxima deposição de gordura nos níveis de 3.000 e $3.300 \mathrm{kcal} /$ energia digestível. As equações obtidas foram $\mathrm{Y}=141,65196$ $-7,95017 \mathrm{x}+0,12297 \mathrm{x}^{2}\left(\mathrm{R}^{2}=0,99\right)$ com estimativa de máxima deposição de gordura em $32,30 \%$ de proteína digestível no nível de $3.000 \mathrm{kcal} / \mathrm{kg}$ energia digestível e $\mathrm{Y}=181,46821$ $11,20517 x+0,18724 x^{2}\left(R^{2}=0,95\right)$ e estimativa de máxima deposição de gordura no nível de $29,90 \%$ de proteína digestível para o nível de $3.300 \mathrm{kcal} / \mathrm{kg}$ de energia digestível.

Para o nível de $3.600 \mathrm{kcal} / \mathrm{kg}$ de energia digestível, não houve efeito $(\mathrm{P}>0,05)$ do aumento dos níveis de proteína digestível sobre a deposição de gordura, demonstrando 
Tabela 6 - Umidade, proteína bruta, matéria mineral e extrato etéreo do filé de juvenis de tilápia-do-nilo alimentados com rações com diferentes relações energia digestível:proteína digestível com base no conceito de proteína ideal

\begin{tabular}{|c|c|c|c|c|c|c|}
\hline Energia digestível (kcal/kg) & Proteína digestível (\%) & Umidade $(\%)$ & Proteína bruta $(\%)$ & Matéria mineral $(\%)$ & Extrato & etéreo $(\%)$ \\
\hline \multirow[t]{3}{*}{3.000} & 22,0 & $76,83 \pm 0,55$ & $19,50 \pm 0,70$ & $1,07 \pm 0,02$ & 1,24 & $\pm 0,04$ \\
\hline & 26,0 & $77,76 \pm 1,23$ & $18,48 \pm 0,62$ & $1,01 \pm 0,19$ & 1,24 & $\pm 0,20$ \\
\hline & 30,0 & $79,08 \pm 0,46$ & $17,75 \pm 3,79$ & $0,87 \pm 0,24$ & 1,26 & $\pm 0,12$ \\
\hline \multirow[t]{3}{*}{3.300} & 22,0 & $77,74 \pm 1,20$ & $18,94 \pm 0,98$ & $1,04 \pm 0,08$ & 0,95 & $\pm 0,04$ \\
\hline & 26,0 & $77,33 \pm 0,96$ & $19,47 \pm 0,93$ & $1,05 \pm 0,07$ & 0,99 & $\pm 0,03$ \\
\hline & 30,0 & $77,09 \pm 0,52$ & $19,43 \pm 0,46$ & $0,91 \pm 0,09$ & 0,88 & $\pm 0,05$ \\
\hline & 26,0 & $76,82 \pm 0,99$ & $19,40 \pm 0,86$ & $1,02 \pm 0,13$ & 0,95 & $\pm 0,09$ \\
\hline & 30,0 & $76,52 \pm 0,70$ & $19,91 \pm 0,67$ & $0,99 \pm 0,11$ & 0,85 & $\pm 0,11$ \\
\hline & 34,0 & $77,67 \pm 2,51$ & $18,85 \pm 1,93$ & $0,88 \pm 0,11$ & 0,91 & $\pm 0,01$ \\
\hline \multicolumn{2}{|c|}{ Nível de energia digestível ( $\mathrm{kcal} / \mathrm{kg}$ ) } & NS & NS & NS & \multicolumn{2}{|r|}{ * } \\
\hline \multicolumn{2}{|c|}{ Nível de proteína digestível } & NS & NS & NS & \multicolumn{2}{|r|}{$*$} \\
\hline
\end{tabular}

$*=\mathrm{P}<0,05, \mathrm{NS}=\mathrm{P}>0,05$ pelo teste de $\mathrm{F}$.

que, mesmo em níveis altos de energia e proteína digestíveis nas rações, os peixes podem apresentar características de carcaça que não comprometem a qualidade, em virtude do excesso de gordura no filé, desde que avaliados a fase e o peso final desejado para o abate. Os resultados deste estudo se assemelham aos obtidos por Jantrarotai et al. (1998) para o bagre-do-canal, os quais também verificaram a possibilidade de redução na gordura da carcaça com o aumento no nível proteico das rações.

Não houve efeito significativo dos níveis de energia e proteína digestível das rações nem da interação entre esses nutrientes nos valores hematológicos e de glicogênio hepático e muscular (Tabela 7). Os valores hematológicos obtidos neste estudo estão na faixa de normalidade para a espécie, como em trabalhos realizados com esta espécie em condições similares (Barros et al., 2002; Ferrari et al., 2004) e em sistemas de produção diferentes ou mesmo com peixes de captura (Tavares-Dias \& Moraes, 2004).

Valores próximos aos resultados obtidos neste estudo foram reportados por Hrubec \& Smith (2000), que compararam os valores hematológicos de várias espécies de peixes e descreveram valores de hemoglobina de 7,0-9,0 g/dL, volume corpuscular médio de 115-183 fL e concentração de hemoglobina corpuscular média de 22,0$29,0 \mathrm{~g} / \mathrm{dL}$, o que indica bom estado de saúde e não caracteriza sintoma de subnutrição ou problemas relacionados ao excesso de nutrientes, de forma a comprometer a saúde dos peixes. Isso ficou comprovado também pelas características

Tabela 7 - Parâmetros hematológicos e de glicogênio hepático e muscular de juvenis de tilápia-do-nilo alimentados com rações com diferentes relações energia digestível:proteína digestível, com base no conceito de proteína ideal

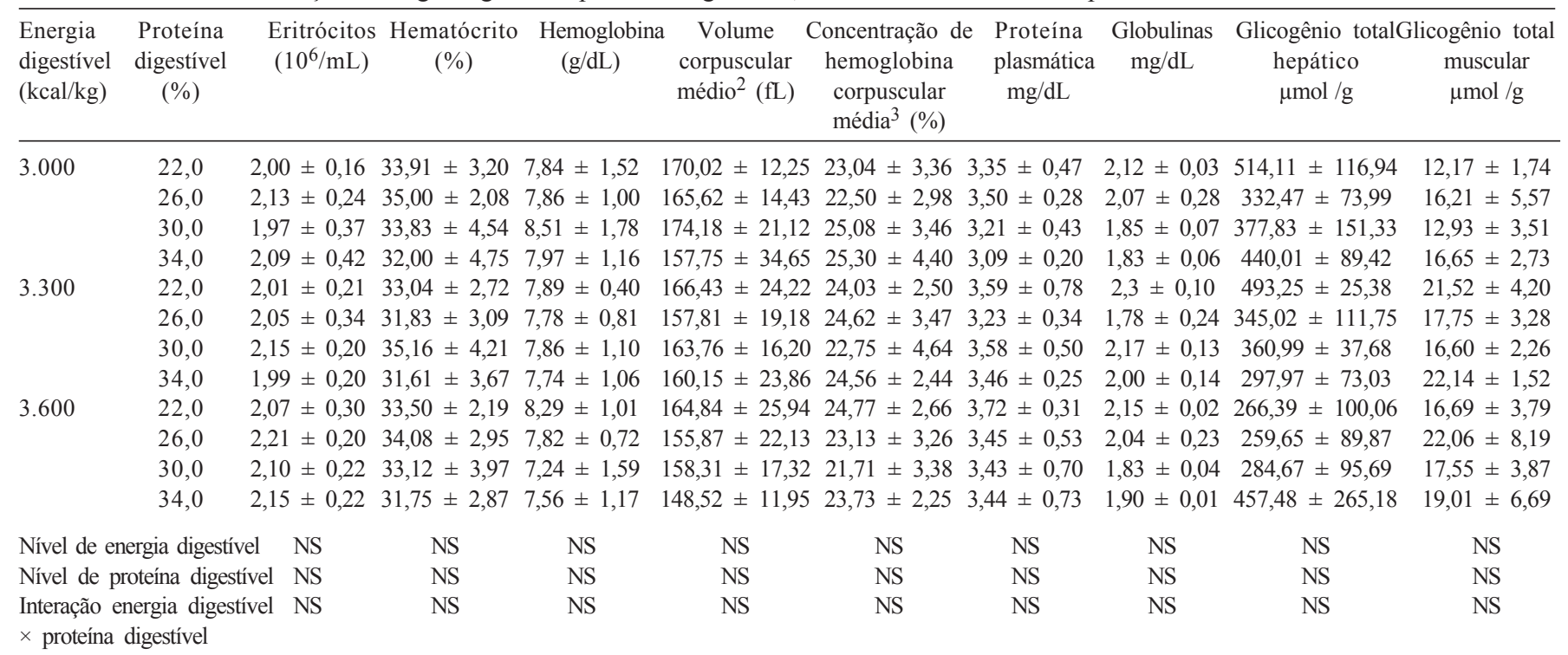

NS $=\mathrm{P}>0,05$ pelo teste $\mathrm{F}$. 
morfológicas do fígado, o qual não apresentou anormalidade decorrente dos níveis de proteína digestível e energia digestível nas rações.

Thomas (2000) ressaltou as centenas de proteínas com diferentes funções, que consistem a proteína plasmática, entre elas, a albumina e as globulinas. Os valores de proteína plasmática encontrados neste estudo foram de 3,09 a 3,72 mg/dL. A concentração de globulinas obtida pela subtração do valor de albumina do total de proteína plasmática indicou que, para todas relações energia:proteína digestíveis, os valores ficaram dentro dos padrões normais (Thomas, 2000).

Observou-se decréscimo no custo de ração/kg de ganho de peso dos peixes à medida que os níveis de proteína digestível aumentaram até o nível de 30\% proteína digestível (Tabela 8). Entretanto, independentemente do nível energético, rações com 34\% proteína digestível apresentam custo superior em relação a todos os outros níveis, comprovando que o excesso de proteína, além de não proporcionar melhores resultados de desempenho produtivo, encarece as rações e podem promover maior aporte de nutrientes para o meio ambiente.

Entre os níveis avaliados, o de $30 \%$ de proteína digestível e $3.000 \mathrm{kcal} / \mathrm{kg}$ de energia digestível (relação $\mathrm{ED} / \mathrm{PD}=100$ ) foram os melhores para o custo/kg de ganho em peso e melhor índice de eficiência econômica para juvenis de tilápia-do-nilo (Tabela 8). Neste estudo, níveis mais elevados de energia digestível não aumentaram a eficiência de utilização da proteína da dieta, assim como níveis superiores de proteína digestível não resultam em ganho econômico, uma vez que as rações foram formuladas de modo atender às exigências em nutrientes digestíveis com a utilização de alimentos convencionais de alto valor biológico para a espécie em estudo.

Tabela 8 - Médias do custo por kg de ração, custo de ração por kg de ganho em peso e índice de eficiência econômica de juvenis de tilápiado-nilo alimentados com as rações experimentais

\begin{tabular}{|c|c|c|c|c|c|}
\hline $\begin{array}{l}\text { Energia digestível } \\
(\mathrm{kcal} / \mathrm{kg})\end{array}$ & $\begin{array}{c}\text { Proteína digestível } \\
(\%)\end{array}$ & $\begin{array}{l}\text { Relação energia digestível: } \\
\text { proteína digestível }\end{array}$ & $\mathrm{R} \$ / \mathrm{kg}^{1}$ & $\begin{array}{l}\mathrm{R} \$ / \text { ganho de } \\
\text { peso }\end{array}$ & $\begin{array}{l}\text { Índice de eficiência } \\
\text { econômica }(\%)\end{array}$ \\
\hline \multirow[t]{3}{*}{3.000} & 22,0 & 136,36 & 0,51 & 0,68 & 81,46 \\
\hline & 26,0 & 115,38 & 0,54 & 0,67 & 83,04 \\
\hline & 34,0 & 88,24 & 0,64 & 0,76 & 73,32 \\
\hline \multirow[t]{2}{*}{3.300} & 22,0 & 150,00 & 0,53 & 0,69 & 80,11 \\
\hline & 26,0 & 126,92 & 0,54 & 0,64 & 86,54 \\
\hline \multirow[t]{4}{*}{3.600} & 22,0 & 163,64 & 0,55 & 0,68 & 81,16 \\
\hline & 26,0 & 138,46 & 0,57 & 0,73 & 76,09 \\
\hline & 30,0 & 120,00 & 0,59 & 0,65 & 85,62 \\
\hline & 34,0 & 105,88 & 0,66 & 0,81 & 68,54 \\
\hline
\end{tabular}

${ }^{1}$ Os valores das matérias-primas foram obtidos de empresas processadoras de rações.

\section{Conclusões}

Os valores de $22,0 \%$ proteína digestível e $3.000 \mathrm{kcal} / \mathrm{kg}$ de energia digestível podem ser utilizados em dietas para tilápias-do-nilo, desde que respeitada a exigência dos demais nutrientes e que sejam utilizados alimentos de alto valor biológico.

\section{Literatura Citada}

ASSOCIATION OF OFFICIAL ANALYTICAL CHEMISTS - AOAC. Official methods of analysis. 14.ed. Washington, D.C., 1984. $1141 \mathrm{p}$.

ASSOCIATION OF OFFICIAL ANALYTICAL CHEMISTS AOAC. Official methods of analysis. 17.ed. Gaithersburg, 2000. 1115 p.

AKIYAMA, T.; OOHARA, T.; YAMAMOTO, T. Comparison of essential amino acid requirements with $\mathrm{A} / \mathrm{E}$ ratio among fish species (review paper). Fisheries Science, v.63, p.963-970, 1997.
BANCROFT, J.D.; STEVENS, A. Theory and practice of histological techniques. 4.ed. New York: Churchill Livingstone, 1996. 766p. BARBOSA, H.P.; FIALHO, E.T.; FERREIRA, A.S. et al. Triguilho para suínos na fase inicial, de crescimento e terminação. Revista Brasileira de Zootecnia, v.21, n.5, p.827-837, 1992.

BARROS, M.M.; PEZZATO, L.E.; KLEEMANN, G.K. et al. Níveis de vitamina $\mathrm{C}$ e Ferro para a tilápia do Nilo (Oreochromis niloticus). Revista Brasileira de Zootecnia, v.31, n.6, p.2149-2156, 2002.

BELLAVER, C.; FIALHO E.T.; PROTAS, J.F.S. et al. Radícula de malte na alimentação de suínos em crescimento e terminação. Pesquisa Agropecuária Barsileira, v.20, n.8, p.969-74, 1985. BIDINOTTO, P.M.; SOUZA, R.H.S.; MORAES, G. Hepatic glycogen in eight tropical freshwater teleost fish: Procedure for field determinations of microsamples. Boletim Técnico do CEPTAPirassununga, v.10, p.53-60, 1997.

BRANDT, T.M. Temperate basses, Morone spp., and black basses, Micropterus spp. In: Wilson, R.P. (Ed.). Handbook of nutrient requirements of finfish. Boston: CRC Press, 1991. p.163-166.

CHO, C.Y. Feeding for rainbow trout and other salmonids, with reference to current estimates of energy and protein requirement. Aquaculture, v.100, p.107-123, 1992. 
COLIN, B.; COWEY, C.B.; YOUNG, D.C. et al. Nutrition requirement of fish. Proceedings of the Nutrition Society, v.52, p.417-426, 1993.

DE SILVA, S.S.; GUNASEKERA, R.M.; SHIM, K.F. Interactions of varying dietary protein and lipid levels in young red Tilapia: evidence of protein sparing. Aquaculture, v.95, p.305-318, 1991

DUBOIS, M.; GILLES, K.A.; HAMILTON, J.K. et al. Colorimetric method for determination of sugars and related substances. Analytical Chemistry, v.28, p.350-358, 1956.

DUPREE, H. K.; GAUGLITZ, E.J.; HALL, A.S. et al. 1979. Effect of dietary lipids on the growth and acceptability (flavor) of channel catfish (Ictalurus punctatus). In: WORLD SYMPOSIUM ON FINFISH NUTRITION AND FISH FEED TECHNOLOGY, 1979, Hamburg, Heenemann, Berlin. Proceedings... Hamburg, Heenemann, Berlin, 1979. v.2, p. 87-103.

EL-SAYED, A.M. Study to determine maximum growth capacity and amino acid requirements of Tilapia genotypes. Göttingen. 2002. 106f. Dissertation (Doctor in Agricultural Sciences) - Faculty of Agricultural Sciences, Göttingen, 2002.

EL-SAYED, A.F.M.; TESHIMA, S. Protein ande energy requirements of Nile Tilapia Oreochromis niloticus, fry. Aquaculture, v.103, p.55-63, 1992.

FERRARI, J.E.C.; BARROS, M.M.; PEZZATO, L.E. et al. Níveis de cobre em dietas para tilápia do Nilo (Oreochromis niloticus). Acta Scientiarum, v.26, n.4, p.429-436, 2004.

FURUYA, W.M.; BOTARO, D.; MACEDO, R.M.G. et al Aplicação do conceito de proteína ideal para redução dos níveis de proteína em dietas para tilápia do Nilo. Revista Brasileira de Zootecnia, v.34, n.5, p.1433-1441, 2005

FURUYA, W.M.; BOTARO, D.; NEVES, P.R. et al. Exigência de lisina pela Tilápia do Nilo (Oreochromis niloticus), na fase de terminação. Ciência Rural, v.34, n.5, p.1571-1577, 2004a.

HAFEDH, Y.S.A. Effects of dietary protein on growth and body composition of Nile tilapia, Oreochromis niloticus L. Aquaculture Research, v.30, p.385-393, 1999.

HRUBEC, T.C.; SMITH, S.A. Hematology of fish. In: FELDMAN, B.F.; ZINKL, J.G.; JAIN, N.C. (Eds.) Schalm's veterinary hematology. 5.ed. Philadelphia: Edgarder Blücher, 2000, p. $1120-1125$.

JANTRAROTAI, W.; SITASIT, P.; JANTRAROTAI, P. et al. Protein and energy levels for maximum growth, diet utilization, yield of edible flesh and protein sparing of hybrid Clarias catfish (Clarias macrocephalus x $C$ gariepinus). Journal World Aquaculture Society, v.29, n.3, p.281-289, 1998.
KAUSHIK, S.J.; OLIVA-TELES, A. Effect of digestible energy on nitrogen and energy balance in rainbow trout. Aquaculture, v.50, p.89-101, 1986.

LOVELL, T. Nutrition and feeding of fish. New York: Van Nostrand Reinhold, 1989. p.11-18.

NATIONAL RESEARCH COUNCIL - NRC. Nutrient requirement of fish. Washington, D.C.: National Academy Press, 1993. 114p.

PAGE, J.W.; ANDREWS, J.W. Interaction of dietary levels of protein and energy on Channel catfish (Ictalurus punctatus). Journal Nutrition, v.103, 1339-1346, 1973

PORTZ, L. Relação energia: proteína na nutrição do "Black Bass” (Micropterus salmoides). 1999. 88f. Dissertação (Mestrado em Agronomia) - Escola Superior de Agricultura Luiz de Queiroz, Piracicaba, 1999.

RODEHUTSCORD, M.; BORCHERT, F.; GREGUS, Z. et al Availability and utilization of free lysine in rainbow trout (Oncorhynchus mykiss). Comparison of L-lysine-HCl and L-lysine sulphate. Aquaculture, v.151, p.177-183, 2000.

SAMPAIO, A.M.B.M. Relação energia: proteína na nutrição do tucunaré (Cichla sp). 1998. 49f. Tese (Dissertação de Mestrado) Escola Superior de Agricultura "Luiz de Queiroz", Piracicaba, 1999.

STATISTICAL ANALYSIS SYSTEMS - SAS. Use's guide, version 6. 4.ed. Cary: SAS $^{\circledR} / \mathrm{STAT}$, SAS Institute, 1995. 365p.

TACON, A.G.J.; COWEY, C.B. Protein and amino acid requirement. In: TYTLER, P.; CALOW, P. Fish energetics: new perspectives. London: Croom Helm, 1985. p.155-193.

TAVARES-DIAS; MORAES, F.R. Hematologia de peixes teleósteos. Ribeirão Preto: Villimpres, 2004. 144p.

THOMAS, J.S. Hematology of fish. In: FELDMAN, B.F.; ZINKL, J.G.; JAIN, N.C. (Eds.) Schalm's veterinary hematology. 5.ed. Philadelphia: Edgarder Blücher, 2000. p.891-898.

WILSON, R.P. Amino acids and proteins. In: HALVER, J,E. (Ed.) Fish nutrition. London: Academic Press, 1989. p.111-151.

WILSON, R.P.; POE, W.E. Relationship of whole and egg essential amino acid patterns to amino acid requirement patterns in channel catfish (Ictalurus punctatus). Compendium Biochemistry Physiology, v.80B, p.385-388, 1985.

WINFREE, R.A.; STCKNEY, A.A. Effects of dietary protein and energy on growth, feed conversion efficiency and body composition of Tilapia aurea. Journal of Nutrition, v.111, p.1001-1012, 1981.

YAMADA, S.; SIMPSOM, K.; TANAKA, Y. et al. Plasma amino acid changes in rainbow trout force-fed casein and corresponding amino acid mixture. Bulletin of the Japanese Society for Scientific Fisheries, v.47, p.1035-1040, 1981. 